\title{
The Politics of Culture and the Culture of Politics: Examining the Role of Politics and Diplomacy in Cultural Property Disputes
}

\author{
Maria Shehade*
}

\author{
Kalliopi Fouseki ${ }^{\dagger}$
}

\begin{abstract}
This article constitutes the first systematic attempt to synthesize the role of politics as an affecting dynamic during the negotiation of cultural property disputes. The article limits its scope to disputes concerning the ownership of cultural artifacts between states and museums settled through negotiation and to the subsequent claims for the return of the contested objects. The discussion focuses on four ways in which the negotiation process is affected when states act as claimants, including the discourse and argumentation used, the available means to pressure the other party to negotiate, the possible political interventions, and the international political scene and its effect on the development of the dispute. Through the examination of multiple case studies, it is argued that in such disputes, several elements related to the role of politics are at interplay affecting the evolution of the negotiation process. Finally, it is also argued that the role of politics as an affecting dynamic during the negotiation process is multi-dimensional, consisting of many different interrelated dynamics that can potentially alter the course of the process.
\end{abstract}

\section{INTRODUCTION}

This article constitutes the first systematic attempt to synthesize the role of politics as an affecting dynamic during the negotiation of cultural property disputes. Cultural property disputes cover such a wide scope of different issues relating to

${ }^{\star}$ Institute for Sustainable Heritage, University College London, United Kingdom; Email: maria. shehade.09@ucl.ac.uk (corresponding author)

†Institute for Sustainable Heritage, University College London, UK; Email: kalliopi.fouseki@ucl.ac.uk 
cultural property that they can often cause ambiguities. In addition, this type of dispute may have a variety of stakeholders or involved parties and a variety of issues under discussion that make an analysis of its entirety difficult, if not unviable. The diversity of cultural property disputes points toward a more focused examination, analyzing these cases separately according to the type of issue under discussion, the type of involved stakeholders, and the type of resolution process used. Thus, this article will limit its scope to disputes concerning the ownership of cultural artifacts between states and museums settled through negotiation and to the subsequent claims for the return of the contested objects. The article examines for the first time how politics affect the negotiation process, especially in cases where the claiming party is a government instead of an individual or an organization. ${ }^{1}$

Although "negotiation is the means more frequently used for the settlement of disputes over the restitution of cultural assets," 2 to our knowledge, no research has been conducted on the range of possible dynamics that can influence a negotiation process, apart from the purely legal ones. ${ }^{3}$ This article reviews the role of one of the factors (possibly, the most critical) that influences a negotiation process-that of politics. In detail, the article discusses four ways in which the negotiation process is affected when states act as claimants, including the discourse and argumentation used, the available means to pressure the other party to negotiate, the possible political interventions, and the international political scene and its effect on the development of the dispute.

The synthetic and systematic review of the role of politics in negotiations over the return of cultural objects claimed by states is based on desktop and case study research. The latter has been informed by the development of an extensive database of more than 100 cases of disputes resolved through negotiation. This article will refer to some of these case studies in order to reinforce some of the key findings emerging from the desktop research. The article begins with a short introduction to cultural property disputes and a brief overview of current resolution practices in order to set the analysis into the wider context of cultural property disputes. The main part of the analysis examines the characteristics of cases in which governments act as claiming parties and the ways in which this affects the dispute and the negotiating process, with particular emphasis on the role of politics in shaping and affecting the negotiations between the involved parties.

\section{RESOLVING CULTURAL PROPERTY DISPUTES}

Disputes relating to the ownership of antiquities can be very diverse in scope, covering disputes over antiquities that are stolen, illegally excavated ${ }^{4}$ or exported, ${ }^{5}$ plundered during war ${ }^{6}$ or colonial domination, ${ }^{7}$ removed before existing laws were enacted, ${ }^{8}$ and so on. The possible combinations of opposing parties in cultural property disputes are numerous: state versus state, individual versus state or museum (and vice versa), state versus museum (and vice versa), indigenous community versus museum or state, and so on. As will be argued in this article, the type of involved 
parties can affect the developments of a case, the way that it is handled, as well as the possible resolutions under consideration. Thus, such disputes are not only affected by the type of claim and the issue at stake but also by the type of involved parties, as is evident in the examined case studies.

The resolution of such disputes in court, as well as the legal and procedural matters relating to litigation for the return of cultural objects, has been the subject of extensive research. ${ }^{9}$ The fact that many cases do not fulfill all of the legal criteria, making a court outcome very uncertain, ${ }^{10}$ has led many scholars to turn to the examination of the possible benefits that alternative methods of dispute resolution have to offer to such cases. ${ }^{11}$ In cases resolved through litigation, the determining factor is the applicable laws and the facts supporting their possible violation. However, this may not always be the case in disputes resolved through negotiation, in which there can be a range of determining factors, apart from the applicable laws, such as the power dynamics, the available evidence, the politics at play, and the stakeholders involved. Nevertheless, no matter what process a claiming party will choose for resolving a dispute, the current legal regime on the protection of cultural heritage will inform, guide, and shape the process. The fact that negotiation may be chosen by a party does not imply that legal rules will be ignored or overlooked. Since heritage around the world is protected by national laws ${ }^{12}$ and international legal instruments, ${ }^{13}$ these will inevitably form the context in which the dispute will be resolved and will also constitute a "validation tool" for the assessment of the proposals of the two sides and of the final outcome.

Despite the growing number of attempts to focus on alternative processes of resolution and the growing literature on the use of alternative dispute resolution (ADR), ${ }^{14}$ it appears that the process of negotiation and how it works in the context of these disputes has not yet been tackled in great detail. Negotiation can be characterized as a dynamic process, affected by many parameters, one of which is politics. The outcome of a negotiation process is directly affected by the process itself. Thus, more in-depth analyses are needed on how possible parameters can affect the development of the negotiating process and, therefore, its outcome.

The lack of sufficient research on this aspect of the application of ADR to such disputes is rather paradoxical, given that many international organizations are promoting the use of alternative means of dispute resolution for resolving cultural property disputes. For example, the UN Educational, Scientific, and Cultural Organization (UNESCO) encourages negotiation and mediation ${ }^{15}$ through its Intergovernmental Committee for Promoting the Return of Cultural Property to its Countries of Origin or Its Restitution in Case of Illicit Appropriation (UNESCO Intergovernmental Committee). ${ }^{16}$

\section{SHAPING THE DISCOURSE OF THE DISPUTE}

One of the first distinct characteristics of cultural property disputes in which the claiming party is a state is the discourse used by the involved parties to support 
their arguments. The dichotomy created by two different conceptions on the ownership of cultural heritage - the "nationalist" and "internationalist" approach to cultural property-usually predominates the discourse developed in these cases. ${ }^{17}$ The two approaches to cultural property-the nationalist and internationalist approach ${ }^{18}$-were first described by John Merryman, who explains that there are two ways of thinking about cultural property. ${ }^{19}$ The first is "as components of a common human culture, whatever their places of origin or present location, independent of property rights or national jurisdiction." 20 The second is "as part of a national cultural heritage," which "legitimizes national export controls and demands for the repatriation of cultural property." ${ }^{21}$ Hence, the world could be divided, as he points out, into source and market nations. ${ }^{22}$

In most cases of cultural property disputes in which states are involved, it is evident that the discourse used to support the arguments of the parties is shaped by these two, mostly contradictive, approaches. ${ }^{23}$ In the case of claiming states, which usually constitute source countries, the arguments used for supporting the claim reflect in most cases the rhetoric of the nationalist approach ${ }^{24}$ and emphasize issues of national sovereignty and identity. ${ }^{25}$ Thus, in many cases of claims for the return of cultural objects, the rationale behind the claim is based on the importance of the object to the country's national identity and the need to restore the claimed objects to their original context, which is connected to the historical and traditional or even sacred background of a particular nation. ${ }^{26}$ For example, Greece's claim for the repatriation of the Parthenon marbles is an illustrative example of this argumentation. ${ }^{27}$ This case, in particular, moves beyond the role of the object in shaping national identities since what seems to matter for the wider public is the process of repatriation as a symbolic process of social justice rather than the object itself. $^{28}$

Indeed, within this frame of thought, the claimed objects tend to become symbols of a lost past, which is extremely important to the formation of the modern nation's identity. Iconic heritage objects become part of the collective identity and memory since "cultural patrimony can be understood only in terms of cultural memory," which contributes to nationhood. ${ }^{29}$ Therefore, the removal of such objects disrupts social justice: "The displacement of the visual image of a cultural object disrupts the collective memory of identity." 30

On the other hand, museums receiving such claims usually adopt a rhetoric based on aspects of the internationalist approach ${ }^{31}$ and may emphasize their role in providing access to the contested objects to a wider public or even a higher level of safety and protection to the disputed artifact. ${ }^{32}$ In some cases, museums may also argue that national claims on antiquities may be considered to be political claims that serve the purpose of the modern claiming nation since "cultural property is not, and cannot be claimed to be the absolute property of a nation" but, rather, the common heritage of humanity. ${ }^{33}$

During negotiations for the resolution of such disputes, a large part of the discourse used is based on the parties' perceptions of entitlement and on standards 
considered to be fair and legitimate as these are formed by both the current legal regime on the protection of cultural property and the two different conceptions on the ownership of cultural artifacts. This leads to the adoption of a rights-based approach during negotiations. ${ }^{34}$

When parties follow a rights-based approach in negotiations, they attempt to determine who is right based on an independent standard perceived as legitimate or fair. In the case of the disputes in question, both the applicable legal rules and the rhetoric of the nationalist and internationalist approach act as the standard on which the claims are evaluated. ${ }^{35}$ A rights-based approach offers the advantage of providing a sense of fairness to the parties and may reduce uncertainty on future rights or on power imbalances. ${ }^{36}$ However, there are instances in which it may prove unproductive, as in cases in which the facts of the case are not clear and not covered by existing laws or in which the legal burden of proof cannot be met to the extent that it would be sufficient to vindicate such a claim in court. ${ }^{37}$

Thus, it has been argued that in cases that are difficult to pursue in court due to legal requirements and in which a rights-based approach is followed in negotiations, the discourse used is based on "broader normative claims regarding a presumption for where an object should be located." 38 The nationalist and internationalist approach used by the involved parties are typical normative claims used in this respect. In the absence of clear and strong evidence to support a claim based solely on legal arguments, the conflict between these two positions is not easily resolved. Thus, the adoption of this discourse and of a purely rights-based approach during negotiations in such cases may "trap" the parties, locking them into positions that cannot always be supported or enforced by the existing laws.

An example that illustrates this situation is the claim by Italy for the return of the Bronze Statue of a Victorious Youth (also known as Athlete of Fano or Getty Bronze) from the J.P. Getty Museum. The statue was discovered in the sea by Italian fishermen in 1964 and was bought by the museum in $1977 .{ }^{39}$ Since its discovery, many investigations on the origin of the statue have been carried out, and several court judgments have been issued in Italy with regard to both the fishermen who had discovered the statue and the Getty Museum's acquisition. ${ }^{40}$ The Italian side claims that the statue constitutes illegally traded and stolen state property that was smuggled out of Italy without the appropriate export licenses and that, therefore, the museum does not have a clear title. ${ }^{41}$ On the other hand, the museum claims that the statue was found in international waters and was purchased through legal channels in good faith. ${ }^{42}$

The statue was also the subject of intense negotiations between the two sides in 2006 and 2007 as part of a dispute concerning many other objects claimed from the museum by Italy. The claims of the two sides on the statue have brought the negotiations to a standstill on many occasions since Italy has insisted that the statue should be included in the final agreement, while the museum has insisted that the fate of the statue cannot be discussed together with the other contested artifacts. ${ }^{43}$ An agreement was finally reached in 2007, only after it was decided that the negotiations 
for the statue should be set aside until the final results of a new criminal investigation, which had begun in Italy on the exportation of the statue. ${ }^{44}$

Although, in 2010, the Italian court ruled that the bronze had been smuggled out of Italy and ordered the museum to return the piece, the dispute is still ongoing, and its return is highly uncertain. ${ }^{45}$ Thus, the approach followed in the negotiations, solely based on a rights discourse and on positions that either could not be proved or supported by the applicable laws or that could not be enforced by the laws in place, have resulted in a dispute that is still ongoing after almost 30 years. In essence, it can be argued that in cases in which states are acting as the claiming parties, and in the absence of a strong legal basis or evidence for the support of the arguments used, the parties resort to other normative claims based on the nationalist and internationalist approaches, following a purely rights-based approach. ${ }^{46}$ Since the "conflict between these two positions is not easily resolved," there is a high possibility for the parties to remain trapped in long and unresolved disputes. ${ }^{47}$

\section{EXERCISING GOVERNMENTAL PRESSURE: MEANS AVAILABLE AND THREAT CAPACITY}

Another major difference in the cases involving governments is the means available to them to bring the other party to the negotiating table and to pressure them toward resolution. First, many governments have a range of international laws and legal instruments that can be used for claiming cultural objects, such as the 1970 UNESCO Convention on the Means of Prohibiting and Preventing the Illicit Import, Export and Transfer of Ownership of Cultural Property (UNESCO Convention), the 1995 UNIDROIT Convention on Stolen or Illegally Exported Cultural Objects (UNIDROIT Convention), and the European Directive 2014/60/EU on the Return of Cultural Objects Unlawfully Removed from the Territory of a Member State. ${ }^{48}$

For example, Articles 3 and 4 of the 1995 UNIDROIT Convention include provisions for the restitution of cultural objects, while Articles 5 to 7 include provisions for the return of illegally exported cultural objects. ${ }^{49}$ Council Directive 2014/60/EU also protects cultural objects that are considered by member states as "national treasures" and includes provisions describing the process that EU states should follow for requesting the return of cultural objects. ${ }^{50}$

There are also cases in which international organizations have stepped in to assist governments in recovering claimed artifacts. For example, in 1995, UNESCO asked the Metropolitan Museum for the return of a Buddha sculpture on behalf of Afghanistan. ${ }^{51}$ More recently, UNESCO provided assistance to Cambodia in the country's attempt to recover a complex of sculptures from Koh Ker that were held by auction houses and museums such as the Metropolitan Museum and Sotheby's. ${ }^{52}$

A number of cases were also resolved with the assistance of the UNESCO Intergovernmental Committee. The last two cases, which are the most recent, are the case of the Sphinx of Bogazkoy, which is a dispute between Turkey and Germany 
that had been pending since 1975 and was resolved in 2010 with the signing of a memorandum of understanding and the return of the sphinx to Turkey, ${ }^{53}$ and the case of the Makonde Mask, which was resolved in June 2010 when the BarbierMueller Museum of Geneva returned the stolen mask to the National Museum of Tanzania. Currently, the only case pending before the committee is the case of the Parthenon marbles.

Second, cultural sanctions have proved to be a very powerful tool in the hands of claiming states, and there are many cases in which governments have used such power to pressure the other side. Cultural sanctions can be used by claiming states as leverage either before negotiations (to pressure the other side to negotiate) or during negotiations (to pressure the other side to make concessions and reach an agreement). In these cases, such sanctions work as bargaining tools that strengthen the claiming state's bargaining power. Thus, they can also change power balances during negotiations and give negotiating power even to countries that feel or appear to be in a weaker position.

The most illustrative example of using cultural sanctions is the case between Italy and the J.P. Getty Museum, which was eventually resolved in 2007. When negotiations between the two sides came to an impasse in April 2007, Italy announced that it would be imposing a "cultural embargo" on the Getty Museum. ${ }^{54}$ The threatened embargo meant that the Getty would not be able to receive loans from Italy and that the government's collaboration in Getty research and conservation projects in Italy would be suspended. ${ }^{55}$ During that time, several requests from the Getty Museum to borrow Italian art for upcoming exhibitions in Los Angeles were delayed or ignored by the Italian authorities. ${ }^{56}$ When the negotiations came to an impasse, the embargo seemed to affect the projects and scheduled exhibitions of the Getty Museum..$^{57}$ As the announced date for the initiation of the embargo was approaching, the two sides felt more pressure to reach an agreement. Eventually, the agreement came just a few days before the full embargo was scheduled to take effect. Although it was not the sole reason for the achieved resolution, the threat of an embargo nevertheless played a role in the developments.

This is not the only example since there are many cases in which claiming governments have interrupted scientific collaborations, denied loans for exhibitions, or threatened to cancel excavation permits provided to the institutions in question. For example, in 2009, the Louvre returned to Egypt five fresco fragments that were illegally taken from a tomb in the Valley of the Kings. The return came only after Egypt suspended its collaboration with the museum for exhibitions, cancelled a lecture in Egypt by a former Louvre curator, and suspended an excavation sponsored by the Louvre at the necropolis of Saqqara. ${ }^{58}$ Another example is the case involving Egypt and the Boston Museum of Fine Arts. In 1988, the museum returned nine fragments of tomb paintings to Egypt, and its director noted that one of the reasons for his decision was that he did not want to jeopardize the museum's relationship with Egypt since the country's cooperation enabled the museum to sponsor many of its digs in the country. ${ }^{59}$ 
Turkey is also one of the countries that has used cultural sanctions in many cases in the past. In recent years, "Turkey threatened to bar foreign archeologists from excavation sites in the country by not renewing their digging permits if governments refuse to return artefacts" and has also "threatened to halt the lending of its treasures to foreign museums." 60 The case of the Sphinx of Bogazkoy, which was returned to Turkey by Germany in 2011, is a prime example. ${ }^{61}$ Before the return of the Hittite statue, Turkey threatened Germany with the non-renewal of excavation permits. In particular, the German Archaeological Institute lost its excavation rights for the ancient Roman town of Aizanoi, in which it had worked since $1926 .{ }^{62}$

The same events happened in an ongoing dispute between Turkey and the Louvre for an Ottoman tile panel from the Piyale Pasha mosque that the Louvre acquired in 1985. The panel is one of the highlights of a new wing of Islamic art launched by the museum in 2012. As a result of this outstanding dispute, the French lost their license for the excavation of the Lycian city of Xanthos in 2011, which had been funded by the French Foreign Ministry since $1950 .{ }^{63}$

Another example is the case of the "Troy Gold," a collection of antique jewelry that was returned as an indefinite loan to Turkey in 2012 from the Pennsylvania Museum of Archaeology and Anthropology. The excavation projects of the University of Pennsylvania had played a role in the settlement of the dispute since the university had been excavating the site of Gordion in Turkey since 1950 under the directorship of a university professor who was also a curator at the museum. ${ }^{64}$ In many cases in the recent past, Turkey has also denied loans to foreign museums from which it was demanding the restitution of objects, such as the British Museum and the Metropolitan Museum in New York. ${ }^{65}$

The basic issue that should be stressed here is the effect that these means have on the dispute resolution process when compared to cases involving individuals or institutions. In a dispute resolution process, such measures produce power-based approaches to the resolution of these disputes, which are affected by the power that the foreign government can exert on the museum or cultural institution of another country. ${ }^{66}$ Through such measures, the bargaining power of the claiming state increases during the negotiations, creating more chances for an outcome that is more favorable for the state.

Although, in many cases, such measures and sanctions work as leverage and bring parties to the negotiating table or pressure them to agree to return the requested objects, they can also have some negative results. It has been acknowledged that power-based approaches can harm the relationship between the parties and their cooperation on many other issues, apart from the implementation of a possible agreement. ${ }^{67}$ For example, Grant Strother acknowledges that cultural property disputes with a power-based frame can lead parties to "feel as if the negotiation was a zero-sum win-lose game or a compromise in which neither party feels good about the result but both can co-exist until the next opportunity for conflict and a win."68 Therefore, the means available to claiming states in a cultural property dispute facilitate the adoption of power-based approaches, which can affect the course of 
the dispute, on the one hand, but can also harm the relationship between the two parties, on the other.

\section{INTERNATIONAL POLITICS AND FOREIGN AFFAIRS}

Cases of cultural property disputes involving states are often affected by the international political scene in several ways. First, the relation between two countries can either facilitate the resolution of such disputes (in the case of good relations and collaboration at a governmental level or through established agreements) or create obstacles for settlement (if such relations are not in place). Second, cultural property disputes may be affected by current political agendas, either in the wider context of international relations or in internal political scenes.

\section{Inter-State Relations}

First, the relations between two countries at a political level can be reflected in cultural property disputes, and the good relations between two countries can help toward the resolution of a pending case. This can also work in reverse, and there are cases in which the return of cultural objects has been used as a means to improve the relations between two countries. The case of Iran and the United States illustrates this idea. After years of turbulent relations and after long negotiations, an international agreement for Iran's nuclear program was signed in 2013. However, prior to these negotiations, the resolution of a long-standing claim by Iran helped to ease the way for the talks as a goodwill gesture and an "ice breaker" between the two sides.

The case began in 2003 when a silver chalice in the shape of a mythical winged creature was seized by the US Customs and Border Protection after an art dealer tried to smuggle it into the United States from Iran. ${ }^{69}$ However, although Iran had sought the return of the chalice, the artifact remained in a US customs warehouse, since "decades of frigid relations between Washington and Tehran kept it frozen in bureaucratic limbo."70 In 2013, and before the negotiations for Iran's nuclear program, the chalice was returned to Iran as a gesture of friendship by the United States. $^{71}$

According to the press, the return "was orchestrated by a diplomat at the U.S. Mission to the United Nations who devised a way to work around a 30-year absence in formal relations."72 Such a move was seen at the time as a way to show goodwill and respect to the people of Iran. As Stacey Falkoff notes, "repatriation may be seen as an expression of respect, potentially leading to improved international relations between the source nation and the nation in which the object is located." ${ }^{\prime 3}$ Indeed, although some scholars have suggested that the chalice is a fake, the effects of the return were nevertheless stressed by Iranian diplomats. Iran's cultural heritage chief stressed at the time the importance of cultural diplomacy in this respect and stated: "I adamantly believe in cultural diplomacy, and I believe that 
the thing that could improve relations between US and Iran and soften the harshness of this relationship is cultural diplomacy." 74

Another example is the return of a bronze bell from the United States to Japan in order to foster goodwill between the two countries. ${ }^{75}$ The bell, which belonged to fifteenth-century Buddhist temple in Okinawa, was seized by the US marines in 1945 and was exhibited as a war trophy at the Virginia Military Institute. It was eventually returned in 1991 and was presented by the press at the time as a gesture by the United States to help the region rebuild its culture. ${ }^{76}$

On the other hand, the pre-existence of good relations and collaborations between countries can influence the resolution of a dispute not only in the case of public museums but also for private ones as well. For example, there are cases in which the government of a country has pressured a private museum to resolve a case because of the good relations that the government has had with the claiming country or because of the current political issues at the time. This was seen in the claims of Italy against the Metropolitan Museum and the Getty Museum in 2006.

Italy has had the strong support of the United States because the Americans wanted Italy as an ally to support their external policies, such as gaining Italian permission to fly over Italy en route to the Middle East ${ }^{77}$ and for expanding the US military base in the town of Vicenza. ${ }^{78}$ This has meant that the US government has supported Italian demands by providing assistance during the investigations, even though in one of the cases the involved museum was a private one. One of the best examples of this support was seen in a press conference held in Italy in 2005 concerning the return of three objects from the Getty Museum. Members of the US Justice Department and agents of the Department of Homeland Security's Immigration and Customs Enforcement were present at the press conference, and the Italian cultural minister thanked them for their assistance. ${ }^{79}$

Thus, the existence of good relations and collaboration at a governmental level or even the existence of an intergovernmental agreement or a memorandum of understanding (MoU) may also facilitate the resolution of such disputes. For instance, in cases falling under the 1970 UNESCO Convention, Article 7.b of the convention advises the use of "diplomatic offices," which may involve the seizure of an object by the importing state until a final decision is reached..$^{80}$ As Anne Bandle notes, "the political climate between the two states may be of great importance in such bilateral requests." ${ }^{81}$ For example, the renewal of the MoU between Italy and the United States in 2006 is thought to have facilitated the return of the Euphronios Krater to Italy by the Metropolitan Museum. As Aaron Briggs points out, "although Italy could not have petitioned the US directly under the agreement for the return of the krater, it nevertheless facilitated the krater's return" since "the museum could not have easily dismissed Italy's claims while hoping they would go unnoticed by the public and authorities." 82

Finally, cultural property disputes and repatriation campaigns may affect the foreign relations of a state, which explains the possible interventions of ministries of foreign affairs in such cases. Turkey, which has adopted an aggressive strategy for the repatriation of antiquities, is an illustrative example. The Turkish Ministry 
of Foreign Affairs has intervened to monitor the particular strategy and its impact on the country's international relations. ${ }^{83}$ At the same time, concerns have been raised in Turkey for the new repatriation policy and the consequences that it could have on the country's image abroad and on tourism. ${ }^{84}$

\section{International Relations and Internal Political Scenes}

Another aspect of the effect of politics that should also be taken into account is the use of cultural property disputes for political reasons in the wider context of international relations. This does not imply that these claims are not fair and well justified or that they should have been dismissed because some politicians used them for other reasons. On the contrary, the possible utilization of such claims in the international arena for reasons of politics could never justify any museum receiving such claims to reject them based on such grounds. Such disputes are multifaceted and complicated, touching upon many interrelated issues, and so it is expected that they could extend to other areas, which at first sight seem unrelated, such as politics. This section aims to highlight such potential extensions and connections to the area of politics, without implying that because of these extensions these claims should be dismissed.

A very illustrative example of such connections was the dispute between Russia and Germany on the spoils of World War II. ${ }^{85}$ When the Red Army invaded Berlin during World War II, around 2.5 million cultural objects were removed from Germany and were taken to Russia as war trophies. ${ }^{86}$ However, according to the Russian Ministry of Culture, "less than $10 \%$ of the artworks looted from Germany are still in Russia, after it returned 1.5m between 1955 and 1960." ${ }^{87}$ Russia's official position is that the objects were taken as compensation for the heavy losses that Russia sustained because of the war. Regarding the ownership of the objects, Russia passed a law in 1998, according to which the objects were considered to be the property of the Russian state..$^{88}$

The law was declared "partially unconstitutional" by the Russian Constitutional Court in 1999;89 however, the court "refused to declare the entire law void." 90 In 2000, and after the court's decision, the Duma voted on an amendment of the law. ${ }^{91}$ In 2001, the Russian government also passed a decree to facilitate the implementation of the law. ${ }^{92}$ Although there have been many returns to Germany, German authorities claim that there are still one million objects missing. ${ }^{93}$ Some of the most well-known restitutions include the return of 117 medieval stained glass windowpanes from the Marienkirche church in Frankfurt in 2002 and $2008^{94}$ and the return of 101 paintings to the Bremen Art Museum. ${ }^{95}$

This particular dispute has been ongoing since the early 1990s; nevertheless, the issue has also been used whenever the relations between Germany and Russia face a crisis. The most recent example concerned an exhibition organized at the Hermitage in 2013, which included many of the contested pieces. Angela Merkel, the German chancellor, was invited to open the exhibition, together with the Russian president, Vladimir Putin. However, the attendance of Merkel and Putin was almost 
cancelled, when Russia was informed of Merkel's intension to ask for the return of certain objects during her speech. At first, the opening speeches were cancelled, blaming time constraints, but, in the end, the two leaders found some common ground in order not to create a diplomatic incident and so the opening went ahead as planned. ${ }^{96}$

This incident was illustrative of the relations between Germany and Russia at the time. Merkel had been criticizing Putin for his practices, especially with regard to opposition movements. The Christian Democratic Union Party had also adopted a harsher tone toward the Kremlin, which was "a signal that the German strategy of Ostpolitik based on quiet engagement with the Kremlin has run its course." 97 Some analysts pointed out at that time that "because of this shift by Merkel, she was prepared to speak out about wanting Russia to return the looted art." 98 On the other hand, apart from an indication of a shift in Germany's foreign policies, the official restatement of the claim also contributed to Germany's internal political scene since the federal elections in Germany were three months away, and Merkel appeared more critical of Putin during her campaign. ${ }^{99}$

Indeed, notwithstanding the justification of these claims or the actual facts on the illicit removal of the claimed objects, such disputes have also been used by politicians in the internal political scene. For example, Turkey's aggressive repatriation campaign has been considered to be part of the wider policies of the government of Recep Erdoğan, led by the Justice and Development Party (AKP). ${ }^{100}$ As Maria Teixeira notes, "a strong aspect of AKP's policy was the investment in cultural heritage and particularly the prioritization of archaeological heritage repatriation." ${ }^{101}$ However, this campaign was charged with political issues, relating to the role of Turkey in the region and the stalled talks with the European Union (EU) over Turkey's EU membership. Therefore, many authors have argued that the Turkish repatriation campaign is related to the rejection by European powers and that it signals the determination of the country to turn its back on the West. ${ }^{102}$

Therefore, it can be said that such claims have been used in the wider foreign policy agendas and have been stressed, or even put aside, depending on the relations between the involved countries and the general political climate at the time. This does not mean that these claims were not perfectly legitimate. It just adds another dimension to the examination of these claims and the possible dynamics that can affect the dispute resolution process.

\section{GOVERNMENTAL INTERVENTION: POLITICS AND CULTURAL DIPLOMACY}

Governmental intervention for the resolution of a cultural property dispute has become a common occurrence in such cases. As Bandle notes, "restitution claims have frequently become a political issue, triggering governments to intervene," and they have done so "with increasing enthusiasm and are not afraid to use aggressive 
pressure means on possessors to obtain the return of disputed objects." 103 Such interventions are often made in the context of the wider cultural diplomacy practices of the countries involved. Many scholars have acknowledged the power that cultural diplomacy may have as a means to resolve a large number of issues and conflicts, ${ }^{104}$ as in the aforementioned case of Iran and the United States. In many cases, this is connected to the issue of respect, which is closely associated in many instances with cultural property disputes, since restitution is considered by many countries to be a gesture of respect for the heritage of the claiming country. Thus, it has been acknowledged that "we should no longer think of culture as subordinate to politics. Instead we should think of culture as providing the operating context for politics." 105

Diplomacy in general has been acknowledged as having an influence in conflict resolution processes, and many scholars consider track-two diplomacy as a means of ADR. ${ }^{106}$ In fact, there are many cases in which diplomacy was acknowledged as an important factor to the resolution of a dispute. ${ }^{107}$ The most illustrative example of the role that diplomacy can play in the resolution of such disputes is exemplified by the return of the Nataraja Idol to India from the Norton Simon Foundation in the United States in 1976. In this particular case, diplomacy played a vital role since the case was pursued during the 1970s when there were not many legal instruments to support such claims, and the UNESCO Convention was just beginning to get ratified. When an exhibition, which was to include the idol, was planned at the Metropolitan Museum in 1973, the Indian government managed to block the exhibition with the help of the US Department of State. Moreover, when the idol was sent to the British Museum for restoration in the same year, India exercised political pressure on the UK government to confiscate the idol through Scotland Yard. ${ }^{108}$

There are many examples of the intervention of diplomats, ambassadors, and other government officials in the resolution of cultural property disputes. Such interventions have facilitated resolution in many instances and broken negotiation impasses, such as in the case between Peru and Yale University for the return of a collection from Machu Picchu. ${ }^{109}$ When a first agreement between the parties failed to materialize in 2007, Peru withdrew from negotiations and filed a lawsuit in the United States against the university. The deadlock was broken thanks to the intervention of Christopher Dodd, a US Democratic senator from Connecticut, who was member of the Senate Foreign Relations Committee and chairman of its subcommittee on Latin America. He met many times with Peruvian President Alan Garcia and other government officials as well as with Yale representatives to facilitate a settlement of the dispute. ${ }^{110}$ The senator worked for years with the two parties, and, in 2010, the lawsuit was dropped, and the parties reached an agreement that also provided for an extensive collaboration between the parties.

There was also a similar intervention in the case of the Nataraja Idol claimed by India in 1974 from the Norton Simon Foundation. In this case, Daniel Moynihan, who was then ambassador to India, became involved in many negotiation sessions between the parties and assisted in the resolution of the dispute. ${ }^{111}$ Another example 
is the dispute between two cantons of Switzerland for a collection of objects, including manuscripts and a cosmographical globe. ${ }^{112}$ After the parties had negotiated unsuccessfully for eight years, they requested the confederation's intervention as a mediator in the dispute. The dispute was settled in 2006 between political representatives from both cantons, with the aid of a mediation team assigned by the Swiss government. ${ }^{113}$

This kind of intervention has also occurred in cases with individuals as claiming parties, as in the case of the Blumengarten painting by Emil Nolde, which was claimed by the heirs of Holocaust victims Otto Nathan Deutsch from the Moderna Museet of Stockholm. When several requests to the museum since 2002 failed, the family asked in 2009 for the intervention of the Swedish culture minister, Lena Adelsohn Liljeroth. ${ }^{114}$ Following this development, the case was settled six months later. The latest example involves the agreement for the return of two Schiele drawings from the Leopold Museum in Vienna to the heir of Karl Maylander, which was announced in April 2016. ${ }^{115}$ Although the negotiations between the parties came to a standstill, the agreement was reached following the intervention of the Austrian culture minister, Josef Ostermayer. ${ }^{116}$

Such interventions can also be indirect through the involvement of ministries of foreign affairs. For example, some of the claim letters sent by Turkey to many prestigious museums around the world, in the context of an aggressive strategy for the repatriation of antiquities, were signed by Erdoğan, who was the prime minister at the time, in an attempt to illustrate that the new policy had the approval of the prime minister himself. ${ }^{117}$ In the aforementioned case between Peru and Yale University, Peruvian President Alan Garcia wrote a letter to US President Barack Obama "to request his help in recovering the artefacts." 118 As Rosemary Listing notes, "in the wider scope of repatriation tactics, this maneuver by Peru had the capacity to reduce the artifacts to contested and undesirable property" in Yale's possession. ${ }^{119}$

However, it should be noted that there have been cases in which such interventions have yielded the opposite results and created even more tension between the two sides. For example, in the case between Italy and the Getty Museum initially involving a total of 52 objects, ${ }^{120}$ the Getty's lawyer asked the help of US ambassador in Rome, Ronald Spogli. ${ }^{121}$ This move created tension between the two sides since it was perceived by the Italians as an effort by the Getty Museum to gain sympathy from the Italian government. Italian officials were offended by Spogli's inclusion in the negotiations, something they interpreted as a clear attempt to "politicize the cultural negotiations." 122 Therefore, although diplomatic interventions may facilitate the resolution of such disputes, they can also create misunderstandings and be perceived badly by the other side.

\section{THE IMPACT OF POLITICS IN NEGOTIATION DYNAMICS}

From this analysis, it would seem that several elements relating to the role of politics are at play during a negotiation process and can affect its evolution. This section 
summarizes these elements and their influence on negotiations. It was emphasized that the adoption of rights-based approaches can lead the parties to an adversarial, win-lose frame in the dispute, ${ }^{123}$ which can harm their relationship and also increase the possibilities for a deadlock. The same applies to power-based approaches, which again can harm the parties' relationship and cause impasses or even a recurrence of disputes.

A party's sanction power as well as its availability of means to resort to during the negotiations increases its bargaining power, ${ }^{124}$ which in turn increases the pressure on the other side to either negotiate or concede. Moreover, high sanction power is one of the main instigators of power-based approaches. It also would seem that the aggressive profile of a claiming country during the pursuit of a claim can affect its negotiating profile and can harm the relation or communication of the two parties, which, in turn, could make an agreement harder to achieve. Finally, cultural diplomacy can increase the bargaining power of a state during negotiations by cultivating the relations of the claiming state with the country that the museum receiving the claim is located, increasing the chances for agreement. This, in turn, can potentially pressure the museum to negotiate.

Thus, the role of politics as an affecting dynamic during the negotiation process is multi-dimensional, consisting of many different interrelated dynamics that can potentially alter the course of the process. However, as is evident from the preceding analysis, this is not absolute since the effect of these dynamics can be different in each case. For example, political interventions into a negotiating process can either facilitate a resolution or create tension between the parties. This is because each of the aforementioned dynamics is not isolated but, rather, constitutes part of a wider matrix of interrelated affecting dynamics. These interrelated affecting dynamics may either relate to politics or to other parameters, such as the available evidence, the power of the parties, media attention, public pressure, and so on. Thus, one should have a comprehensive understanding of all of the interrelated dynamics so as to be able to understand the full range of their potential effects on the negotiating process. Uncovering the complex dynamics of one of these parameters will illuminate only one of the many possible aspects of these disputes.

This summary of the dynamics of politics in cultural property disputes is illustrative of the complexity of such cases and indicates that similar analyses should be carried out for many other elements that can affect the negotiating process. Such research can shed more light on this highlighted complexity of these cases and further our understanding of cultural property disputes.

\section{CONCLUSION}

This article has attempted to synthesize for the first time the possible differences that may be encountered in the out-of-court negotiating process in cases where the claimant of a cultural object is a state. It has endeavored to unpack through a systematic review of the literature and relevant case studies the role of politics in 
shaping negotiation processes around the repatriation of cultural objects claimed by a state. The article provides a starting point for further research on the role of politics and other factors that affect the negotiations of cultural property disputes.

It has become obvious that cultural property disputes are usually very complex, with many factors affecting different aspects at play, from legal implications to archeological and ethical factors. Thus, it is expected that because of this complexity the resolution of these disputes will be affected by all of these separate issues. The article argues that several elements related to the role of politics are at play affecting the evolution of a negotiation process. Specifically, it notes that the adoption of a rights-based approach tends to cultivate a win-lose attitude among the parties, increasing the possibility for a deadlock. The available means of a party and its sanction power inevitably increase its negotiating power, exercising pressure on the other side, which may facilitate an agreement. The higher the sanction power, the more likely it is for a party to adopt a power-based approach, fostering a win-lose situation, which is harmful for the relationship of the parties and for the recurrence of disputes. Cultural diplomacy, on the other hand, can be pivotal in cultivating the relations of a claimant with the museum's country increasing the chances for agreement.

More importantly, it is argued that disputes regarding the ownership of cultural artifacts, settled through negotiation, are not only affected by the type of the dispute and the issue at stake (that is, whether the object was removed during colonial domination, if it was illicitly excavated, and so on) but also by the type of parties involved (be it states, individuals, communities, or other organizations). As revealed in this article, the type of claimant can change the argumentation and discourse used during negotiations, the means available to pursue the claim or to pressure the other side to negotiate, and the available remedies under examination and may also introduce certain other parameters to the negotiating process that may affect the development of the case.

In particular, the article has argued that when the claimant is a state and negotiations are selected for the settlement of the case, the negotiation process is affected in four different ways. First, the discourse and argumentation used is usually based on the dichotomy between the nationalist and internationalist approach to cultural property, following a purely rights-based approach. In the absence of a strong legal basis or evidence for the support of the arguments used, this creates a high possibility for the parties to remain trapped in long and unresolved disputes. Second, the claiming governments have a range of available means to pressure the other party to negotiate, such as cultural sanctions, which promote a power-based approach, which, in turn, can complicate the dispute and make a solution harder to achieve. Third, it was illustrated that the international political scene and the relationship between countries can affect the dispute, either by facilitating resolution or by creating obstacles when these relationships are disturbed. Finally, the same applies to interventions of diplomats during the negotiating process. 
The first two means are internal characteristics relating to the nature of the claimant per se and its abilities or available means. The last two can be considered as external characteristics since they relate to the role of politics, which may exert both positive and negative influences on the negotiations. In essence, when states act as claiming parties, it is inevitable that various manifestations of politics and the wider socio-political, national, and international context will influence the negotiating process and act as external affecting parameters that should be taken into account, apart from the applicable laws or the available evidence.

Through this analysis, it has become apparent that there is a very complex set of issues affecting such cases and that, when dealing with such a case, one should be aware of all of these issues and have a comprehensive understanding not only of the legal regime applying to these cases but also of the international political arena. This article has attempted to contribute to the comprehensive understanding of one of the many factors that can affect the resolution of cultural property disputes-that of politics. However, since each case is unique, more work needs to be done in this respect, and research relating to these disputes in the future should seek to analyze all of the possible dynamics that can facilitate or complicate resolution. Even with regard to politics, this article should be considered as only a starting point since current ongoing or future cases may shed more light on other possible characteristics and effects of cases involving states and on other influences of diplomacy in the negotiating process of such cases.

\section{ENDNOTES}

1. Although there is an extensive literature available on the legal means available to states for pursuing repatriation claims, covering all of the technical legal characteristics of the in-court aspects of such cases, very little research has been conducted on the out-of-court negotiation aspect of these disputes when states act as claimants and the dynamics that can affect the process itself. For the legal aspect of cases with states as claimants, see, e.g., Francioni and Gordley 2013.

2. Chechi 2013, 188.

3. Many factors affecting the negotiation of cultural property disputes have been indirectly presented or identified in some of the available research. However, the available research does not focus on the influence of these dynamics on the negotiating process, and the examination of these factors is either indirect or lacks the necessary in-depth analysis.

4. See Atwood 2004; Houpt 2006; Nairne 2011. The most recent example is the case of Subhash Kapoor, a New York-based art dealer who is accused of looting over US \$100 million worth of artifacts from India. Many of these artifacts ended up in museums around the world, such as the National Gallery of Australia. See J. Felch, "Federal Agents Comb Records of Disgraced Dealer Subhash Kapoor's Sales and Gifts," The Art Newspaper, 2 June 2015. Another indicative example is the case of the famous Euphronios Krater from the Metropolitan Museum of Art and the golden wreath from the Getty Museum. See Watson and Todeschini 2007; Silver 2009; Felch and Frammolino 2011.

5. As in Attorney General of New Zealand v Ortiz, [1984] AC 1, [1984] 2 WLR 809, which was analyzed in Paterson 1995. This may include cases of privately owned artifacts, which are classified as national treasures and exported without permission. See Hoffman 2009, 90.

6. Refer to Boylan 2001; Chamberlain 2004; and, for the cases of Iraq and Afghanistan, see Bogdanos 2005; Bernhardsson 2006; Rothfield 2008, 2009. 
7. Such as the case of the Venus of Cyrene. See Scovazzi 2009; Chechi 2008; Wilkie 2009.

8. If the removal of the objects occurred before the implementation of existing laws protecting cultural heritage, the claim for the return of the objects is not based on an existing law or prohibition but, rather, on other grounds, such as the importance of the object for the nation and its people, the symbolic importance of the object, or the aesthetic and archaeological unity of the monument from which the object was removed.

9. See, e.g., Kaye 1999; Shapiro 1999; Palmer 2009; Parkhomenko 2011; Chechi 2013, 2014. For the issue of sovereign immunity, which is of particular importance to cases involving states, see Pavoni 2013.

10. For an overview of legal requirements of such cases and possible obstacles faced during litigation, see Kaye 1999; Palmer 2004, 2009; Renold 2009; Stamatoudi 2011.

11. See, e.g., Byrne-Sutton and Geisinger 1999; Nafziger 2004; Palmer 2004; Renold 2009; Stamatoudi 2011; Varner 2012; Chechi 2013.

12. Such as national patrimony laws and export control laws found in many "source" nations such as Greece, Italy, Cyprus, Peru, and so on.

13. Such as Convention on the Means of Prohibiting and Preventing the Illicit Import, Export and Transfer of Ownership of Cultural Property, 14 November 1970, 823 UNTS 231 (UNESCO Convention); Convention for the Protection of Cultural Property in the Event of Armed Conflict, 14 May 1954, 249 UNTS 240 (Hague Convention); Convention on Stolen or Illegally Exported Cultural Objects, 24 June 1995, 2421 UNTS 457 (UNIDROIT Convention). Council Directive (EU) 2014/60 on the return of cultural objects unlawfully removed from the territory of a Member State [2014] OJ L159.

14. See the references in $\mathrm{n} 11$.

15. In a very important development, the committee has added mediation and conciliation to its mandate in 2005, and specific "rules of procedure for mediation and conciliation" have also been developed for the facilitation of bilateral negotiations.

16. The committee was created in 1978 by Resolution 20 C4/7.6/5 (1978) at the twentieth session of the UNESCO General Conference. It is an intergovernmental body with an advisory role, which facilitates bilateral negotiations and provides a framework for discussion and negotiation, but its recommendations concerning inter-state disputes are not legally binding.

17. It is worth noting that the academic discourse used in the context of cultural property disputes is the same as the political discourse used by states to support their claims, which may be due to the fact that this discourse is based on the current legal regime on the trade of antiquities.

18. For a critique of these approaches, see Bauer 2008.

19. Merryman 1986.

20. Ibid., 831.

21. Ibid.

22. The term "source nations" refers to art rich countries such as Greece, Egypt, India, and so on that have a wealth of cultural artifacts for which there is a world market. In the case of "market nations," the demand for cultural objects exceeds the supply, and so demand is covered by imports from source countries. See Hoffman 2009, 89.

23. For the problems created by the two contradictive approaches, see Papa-Sokal 2009.

24. Source countries have introduced a series of laws, whether patrimony laws or export control laws, which protect all antiquities, both excavated and unfound ones, and vest their ownership to the state. For an extensive analysis of the nationalist approach, see Gazi 1990; Hitchens 2008; Papa-Sokal 2009; Greenfield 2013.

25. It is worth noting that when source countries that claimed objects in the past are on the receiving end of a similar claim from another country, they may adopt a different rhetoric from the nationalist approach, or follow the same frame of thought. Since this depends on the country, future research could examine particular cases and compare the discourses used by countries that have both claimed objects and received similar claims for returns.

26. See Hamilakis and Yalouri 1996; Hamilakis 2007. 
27. See Kynourgiopoulou 2011.

28. See Fouseki 2014.

29. Kynourgiopoulou 2011, 162.

30. The strong connection of emblematic heritage objects to national identity and social justice is evident in the Greek argumentation for the Parthenon Marbles' repatriation and the views of the Greek public (Fouseki 2014). For Greeks, "ownership is not a legal issue but an issue of social justice and morality" (ibid., 172). Thus, the marbles' removal did not disrupt only the collective identity, "but the need of Greeks for social justice since they feel the legitimate owners of their heritage" (ibid). For other connections of heritage preservation with social justice, see Fouseki and Shehade 2016.

31. For an extensive analysis of this approach, see Merryman 1986; King 1999; Cuno 2008.

32. E.g., this has been part of the rhetoric used by the British Museum to justify the retention of the Parthenon Marbles claimed by Greece, according to which the museum safeguards the marbles from the consequences of the air pollution of Athens and provides access to them for millions of visitors. See Greenfield 2013.

33. King 1999, 199; see also Warren 1999; Cuno 2008.

34. Based on the framework presented by Ury, Brett, and Goldberg (1988), there are three types of approaches during a dispute resolution process, based on the discourse used: power-based, rightsbased, and interest-based approaches. Power-based approaches rely on who has the most power, and interest-based approaches focus on the parties' interests, in an attempt to find a solution that satisfies the interests of both parties.

35. See Strother 2014.

36. Ury, Brett, and Goldberg 1988; see also Strother 2014.

37. See Strother 2014.

38. Ibid., 367.

39. For an extensive analysis of the facts of the particular case, see Fincham 2014; see also Amineddoleh 2011.

40. For details on court decisions, see Fincham 2014.

41. Amineddoleh 2011, 31.

42. Ibid., 31.

43. See Felch and Frammolino 2011; Fincham 2014.

44. Ibid.

45. It has been argued that it is highly questionable if the Italian police will be allowed to travel to the United States and retrieve the statue since, as noted by Gerstenblith, "if the bronze was found in international waters, rather than Italian national waters, [it is] doubtful that any U.S. court would recognize it as stolen. While the Italians claim that the bronze was illegally exported, illegal export does not, by itself, make the bronze stolen or otherwise illegal in the U.S" (Gerstenblith, quoted in Amineddoleh 2011, 31).

46. A rights-based approach may also be adopted in cases involving individuals. In fact, this is actually expected since the legal rules constitute a typical foundation for supporting such claims during a negotiation process (see Strother 2014). However, cases involving individuals may be based on different legal rules according to the case, and the argumentation used does not relate to the nationalist or internationalist approach to the ownership of cultural heritage.

47. Strother 2014, 367.

48. Council Directive 2014/60/EU of 15 May 2014, which is a recast of Council Directive (EEC) 93/7 of March 1993 and applies as of 19 December 2015. The directive only applies within the European Union.

49. However, it is worth noting that the UNIDROIT Convention has only 37 contracting states, which limits its worldwide applicability. Moreover, both the 1995 UNIDROIT Convention and the 1970 UNESCO Convention are applicable only to the countries that have ratified them.

50. Nevertheless, a 2013 European Union report on the application of Council Directive 93/7/EU, noted the infrequent application of the directive and the financial costs associated with return 
proceedings. See "Fourth Report on the Application of Council Directive 93/7/EEC on the Return of Cultural Objects Unlawfully Removed from the Territory of a Member State," Doc $\operatorname{COM}(2013) 310,30$ May 2013, 7. Moreover, there were only 19 cases of antiquities return under the directive in 2008-11 and only 5 cases in 1999-2003. See also the "Second Report on the Application of Council Directive 93/7/EEC on the Return of Cultural Objects Unlawfully Removed from the Territory of a Member State, Doc COM(2005) 675, 21 December 2005. According to the 2013 report, "the most frequent acts of administrative cooperation carried out by national authorities relate to the search for a cultural object which has been unlawfully removed from their territory, or notification of the discovery of such an object" (8).

51. Refer to "UNESCO Wants Return of Museum Treasure," http://www.upi.com/Archives/1995/05/ 22/UNESCO-wants-returns-of-museum-treasure/8523801115200/ (accessed March 2016); see also Bitterman 2012.

52. See UNESCO's announcement, http://www.unesco.org/new/en/phnompenh/about-thisoffice/single-view/news/return_of_the_warriors/\#.VwduPXrQWLI (accessed March 2016).

53. See Prott 2010. The case was pending since 1975 and was presented to the UNESCO committee in 1987.

54. "J. Paul Getty Museum Responds to the Imposition of a Cultural Embargo by Italy's Ministry of Culture," Getty Museum Press Release, 20 April 2007.

55. See "Italy Issues Getty Ultimatum for Return of Works," Los Angeles Times, 11 July 2007.

56. For more information, see Felch and Frammolino 2011; see also J. Felch and L. Borghese, "Italy, Getty End Rift," Los Angeles Times, 26 September 2007.

57. At that time, the Getty Museum had asked for eight drawings and seven paintings from Italy for an exhibition on Taddeo and Federico Zuccaro, which would open on October 2007. The museum received no response to its request, and so the Getty curators planned for the exhibition without them. However, when the approval finally came after the agreement of the parties, the exhibition was redesigned to accommodate the additional works. The museum also requested an important sculpture of Costanza Bonarelli, which was denied but was reconsidered after the August agreement. See Felch and Borghese, "Italy, Getty End Rift."

58. Refer to Shyllon 2011; Bitterman 2012; see also M. Kimmelman, "When Ancient Artefacts Become Political Pawns," New York Times, 24 October 2009, A1; D. Itzkoff, "Egypt and Louvre Resolve Their Differences," New York Times, 10 October 2009, C2.

59. Refer to Bitterman 2012; C. Temin, "The MFA and the Politics of Plunder," Boston Globe, 4 January 1989, 37.

60. C. Letsch, and K. Conolly, "Turkey Wages 'Cultural War' in Pursuit of Its Archaeological Treasures," The Guardian, 21 January 2013.

61. For an analysis of the case, see Prott 2010.

62. See S. Gusten, “Turkey Presses Harder for Return of Antiquities," New York Times, 25 May 2011.

63. Ibid.

64. Refer to K. Matheson, "Penn Museum Makes Deal with Turkey for 'Troy Gold," Washington Times, 4 September 2012.

65. E.g., a British museum exhibition on the Uluburun ship, along with other loans from Turkey, was dropped because of Turkey's claim for the return of the Samsat stele. See M. Bailey, "Chirac Intervenes in Illicit Art Trade," The Art Newspaper, Issue 104, June 2000. Similarly, the exhibition "Hajj: Journey to the Heart of Islam," went ahead at the British Museum in 2012 without Turkish artifacts for the same reason. See "Of Marbles and Men: Turkey's Cultural Ambitions," The Economist, 19 May 2012. Turkey also denied loans to the Metropolitan Museum for the exhibition "Byzantium and Islam: Age of Transition," which was organized in 2012. See D. Bilefsky, "Seeking Return of Art, Turkey Jolts Museums," New York Times, 1 October 2012, A1. For an exhibition on the Seljuk Islamic empire, see T. Cornwell, "No Turkish Loans for Big Seljuk Turk Show Planned by the Met," The Art Newspaper, Issue 261, 9 October 2014.

66. Refer to note 34 above for definitions. 
67. It has been acknowledged that power-based approaches can result in suboptimal outcomes and make the parties feel as if they are in a contest, which can harm the relationships and also cause a recurrence of disputes. Ury, Brett, and Goldberg 1988.

68. Strother 2014, 366.

69. See T. Kangarlou and B. Brumfield, "2,700-year-old Persian Artefact a Gift of U.S. Diplomacy to Iran?,” CNN, 28 September 2013, http://edition.cnn.com/2013/09/28/world/meast/2700-year-oldpersian-artifact-iran-cultural-diplomacy/ (accessed October 2015).

70. Ibid.

71. See C. Parsons, "The Chalice That Helped Make Possible the Iran Nuclear Deal," Los Angeles Times, 30 November 2013.

72. Ibid.

73. Falkoff 2007, 278.

74. Kangarlou and Brumfield, "2,700-year-old Persian Artefact."

75. Bitterman 2012.

76. See W. Honan, “A 1465 Bell, War Booty, to Go Back to Okinawa,” New York Times, 6 April 1991.

77. See Waxman 2008.

78. See Yeo 2011.

79. Silver 2009, 227.

80. See O'Keefe 2007.

81. Bandle 2012, 226; see also O'Keefe 2007.

82. Briggs 2007, 646-47. The memorandum of understanding is not retroactive and was enforced in 2001, long after the acquisition of the krater by the Metropolitan Museum.

83. M. Bailey, "Turkey Turns up the Heat on Foreign Museums," The Art Newspaper, Issue 236, 13 June 2012.

84. Ibid.

85. For the particular case, see Akinsha and Kozlov 1995; Simpson 1997; Eichwede 2010; Greenfield 2013.

86. Dempsey 2013.

87. See K. Connolly, "Russia-Germany Row over War Loot Mars Exhibition Opening," The Guardian, 21 June 2013.

88. The particular law, entitled Federal Law on Cultural Valuables Displaced to the USSR as a Result of World War II and Located on the Territory of the Russian Federation, Federal Law N64-FZ, 15 April 1998, has been criticized by many scholars since many consider that it violates international law and treaties. See Grimsted 2010; Monten 2004.

89. Decision of the Constitutional Court of the Russian Federation on the Verification of the Constitutionality of Provisions of the Federal Law on Cultural Values Displaced to the USSR as a Result of World War II and Situated on the Territory of the Russian Federation, Case No. 12-P, 20 July 1999.

90. Monten 2004, 73.

91. Amendments and Supplements to the Federal Law on Cultural Treasures Transferred to the USSR during World War II and Held in the Russian Federation, Federal Law N70-FZ, 26 April 2000. For details of the amendment, see Monten 2004; Grimsted 2010.

92. Decree No. 174 on Measures for Implementation of the Federal Law on Cultural Treasures Relocated into the Union of Soviet Socialist Republics as a Result of World War Two and Retained on the Territory of the Russian Federation, 2001.

93. "Russia-Germany Row over War Loot."

94. See "Restoring a Window's Glow, Healing a War's Wounds," New York Times, 27 December 2000.

95. Refer to Eichwede 2010; Greenfield 2013. See also S. Hochfield, "The German-Russian Stalemate," Art News Magazine, February 2011.

96. During her speech, Merkel stressed: "It is our opinion that these exhibition pieces should be returned to Germany," while Putin replied: "We probably should not start a discussion now because people will appear on the Russian side who would evaluate the damage done to our art during World 
War II.” See Dempsey 2013. See also G. Vasagar, “Angela Merkel Calls for Return of Looted German Art from Russia,” The Guardian, 21 June 2013.

97. Dempsey 2013.

98. Ibid.

99. As Dempsey notes, "Merkel was doing some electioneering as well. With less than three months to go before the next federal election, she has been much more critical of Putin." Ibid.

100. See, e.g. "Of Marbles and Men."

101. Teixeira 2015, 38 .

102. See, e.g., Atakuman 2010; Haines 2012; Teixeira 2015.

103. Bandle 2012, 211, 213.

104. See, e.g., Burton and Dukes 1990; Jonsson and Aggestam 2009.

105. Bound et al. 2007, 20.

106. See, e.g., Burton and Dukes 1990, 139. As they explain, track-two diplomacy describes "communication at an unofficial level of matters usually negotiated officially."

107. E.g., the return of the Axum Obelisk from Italy to Ethopia, the Utimut project between Denmark and Greenland for the return of cultural objects, and the return of the Venus of Cyrene from Italy to Libya. For an overview of such cases, see Stamatoudi 2009.

108. See Scott-Rau 1999.

109. For more information on the case, see Swanson 2009; Listing 2011.

110. See J. Christoffersen, "Senator: Artefacts Held by Yale Belong to Peru," Huffington Post, 9 June 2010.

111. Refer to G. Glueck, "Simon and India: Battle on Idol Widens," New York Times, 30 December 1974.

112. The parties in dispute were the canton of Saint-Gall and the canton of Zurich.

113. For more information, see Cornu and Renold 2010.

114. Refer to C. Hickley, "Jewish Heirs, Sweden Settle 7-Year Feud over Nazi-Looted Nolde," Bloomberg, 9 September 2009. See also Bandle 2012.

115. See J. Michalska, "Leopold Museum Returns Two Schiele Drawings to New York Heir," The Art Newspaper, Issue 278, 7 April 2016, http://theartnewspaper.com/news/news/leopold-museumfinally-returns-two-schiele-drawings-to-new-york-heir-/ (accessed March 2016).

116. Ibid.

117. Bailey, "Turkey Turns up the Heat."

118. Listing 2011,78 .

119. Ibid.

120. The final agreement included the return of a total of 40 objects to Italy from the Getty Museum.

121. Before becoming an ambassador, Spogli was a prominent equities investor in Los Angeles and knew some of the Getty trustees. See Felch and Frammolino 2011.

122. J. Felch and R. Frammolino, "Getty Risks 'Embargo,' Italy Warns," Los Angeles Times, 11 November 2006. See also Felch and Frammolino 2011

123. A frame is "a subjective mechanism through which people evaluate and make sense out of situations, leading them to pursue or avoid subsequent actions." Lewicki, Saunders, and Minton 1999,155 . Frames define the way people react during a negotiation, their attitudes, strategies, choices, objectives, and expectations, and so they inevitably affect the final outcome. Negotiators with a negative frame, or a win-lose frame, view the outcome as a potential loss. Thus, they may have more contentious behavior, less concession making, an increased likelihood of escalation and impasse, and a reduced number of achieved agreements. Gelfand, Fulmer, and Severance 2011.

124. Sanction power (also known as threat capacity) refers to the "ability or perceived ability to inflict harm or interfere with a party's ability to apply direct sanctions." Mayer 1987, 78.

\section{REFERENCES}

Akinsha, Konstantin, and Grigorii Kozlov. 1995. Beautiful Loot: The Soviet Plunder of Europe's Art Treasures. New York: Random House. 
Amineddoleh, Leila. 2011. “The Getty Museum's Non-Victorious Bid to Keep the 'Victorious Youth' Bronze." Art and Cultural Heritage Law Newsletter of the Art and Cultural Heritage Law Committee of the ABA Section of International Law 3, no. 1:30-32.

Atakuman, Çigdem. 2010. "Value of Heritage in Turkey: History and Politics of Turkey's World Heritage Nominations." Journal of Mediterranean Archaeology 23, no. 1: 107-32.

Atwood, Roger. 2004. Stealing History: Tomb Raiders, Smugglers, and the Looting of the Ancient World. New York: St. Martin's Press.

Bandle, Anne Laure. 2012. "The Impact of Politics on the Resolution of Art Restitution Claims." In Resolving Disputes in Cultural Property, edited by M. Renold, A. Chechi, and A. Bandle, 211-50. Zurich: Schultess.

Bauer, Alexander. 2008. "New Ways of Thinking about Cultural Property: A Critical Appraisal of the Antiquities Trade Debates.” Fordham International Law Journal 31, no. 3: 690-724.

Bernhardsson, Magnus. 2006. Reclaiming a Plundered Past: Archaeology and Nation Building in Modern Iraq. Austin: University of Texas Press.

Bitterman, Amy. 2012. "Settling Cultural Property Disputes." Villanova Sports and Entertainment Law Journal 19, no. 1: 1-38.

Bogdanos, Mathew. 2005. Thieves of Baghdad. New York: Bloomsbury Publishing.

Bound, Kirsten, Briggs Rachel, Holden John, and Samuel Jones. 2007. Cultural Diplomacy. London: DEMOS.

Boylan, Patrick. 2001. "The Concept of Protection in Times of Armed Conflict: From Crusades to the New Millennium." In Illicit Antiquities: The Theft of Culture and the Extinction of Archaeology, edited by N. Brodie and K. Tubb, 43-108. London: Routledge.

Briggs, Aaron Kyle. 2007. "Consequences of the Met-Italy Accord for the International Restitution of Cultural Property.” Chicago Journal of International Law 7, no. 2: 623-53.

Burton, John, and Frank Dukes. 1990. Conflict: Practices in Management, Settlement and Resolution. New York: St. Martin's Press.

Byrne-Sutton, Quentin, and Fabienne Geisinger-Mariéthoz, eds. 1999. Resolution Methods for ArtRelated Disputes. Etudes en droit de l'art, vol. 11. Zurich: Schulthess.

Chamberlain, Kevin. 2004. War and Cultural Heritage: An Analysis of the Hague Convention on the Protection of Cultural Property in the Event of Armed Conflict. Leicester: Institute of Art and Law.

Chechi, Alessandro. 2008. "The Return of Cultural Objects Removed in Times of Colonial Domination and International Law: The Case of the Venus of Cyrene." Italian Yearbook of International Law 18: 159-81.

2013. "Plurality and Coordination of Dispute Settlement Methods in the Field of Cultural Heritage." In Enforcing International Cultural Heritage Law, edited by Francesco Francioni and James Gordley, 177-205. Oxford: Oxford University Press.

. 2014. The Settlement of International Cultural Heritage Disputes. Oxford: Oxford University Press.

Cuno, James. 2008. Who Owns Antiquity: Museums and the Battle over Our Ancient Heritage. Princeton: Princeton University Press. 
Cornu, Marie, and Marc-Andre Renold. 2010. "New Developments in the Restitution of Cultural Property: Alternative Means of Dispute Resolution.” International Journal of Cultural Property 17, no. 1: 1-31.

Dempsey, Judy. 2013. How Looted Art Haunts German-Russian Relations. http://carnegieeurope.eu/ strategiceurope/?fa=52181 (accessed October 2015).

Eichwede, Wolfgang. 2010. "Trophy Art as Ambassadors: Reflections beyond Diplomatic Deadlock in the German-Russian Dialogue." International Journal of Cultural Property 17, no. 2: $387-412$.

Falkoff, Stacey. 2007. "Mutually Beneficial Repatriation Agreements: Returning Cultural Patrimony, Perpetuating the Illicit Antiquities Market." Journal of Law and Policy 16, no.1: 265-304.

Felch, Jason, and Ralph Frammolino. 2011. Chasing Aphrodite: The Hunt for Looted Antiquities at the World's Richest Museum. New York: Houghton Mifflin Harcourt.

Fincham, Derek. 2014. "Transnational Forfeiture of the Getty Bronze." Cardozo Arts and Entertainment Law Journal 32, no. 2: 471-500.

Fouseki, Kalliopi. 2014. "Claiming the Parthenon Marbles Back: Whose Claim and on Behalf of Whom?" In Museums and Restitution: New Practices, New Approaches, edited by L. Tythacott and K. Arvanitis, 163-78. Farnham: Ashgate.

Fouseki, Kalliopi, and Maria Shehade. 2016. "Heritage Activism and Cultural Rights: The Case of the New Acropolis Museum." In Heritage in Action: Making the Past in the Present, edited by H. Silverman, E. Waterton, and S. Watson. Cham, Switzerland: Springer. In press.

Francioni, Francesco, and James Gordley, eds. 2013. Enforcing International Cultural Heritage Law. Oxford: Oxford University Press.

Gazi, Andromache. 1990. "Museums and National Cultural Property: I. The Question of Restitution." Museum Management and Curatorship 9: 121-35.

Gelfand, Michele, Fulmer Ashley, and Severance Laura. 2011. "The Psychology of Negotiation and Mediation." In APA Handbook of Industrial and Organizational Psychology, vol. 3, edited by Sheldon Zedeck, 495-554. Washington, DC: American Psychological Association.

Greenfield, Jeanette. 2013. The Return of Cultural Treasures, 3rd ed. Cambridge: Cambridge University Press.

Grimsted, Patricia Kennedy. 2010. "Legalizing 'Compensation' and the Spoils of War: The Russian Law on Displaced Cultural Valuables and the Manipulation of Historical Memory.” International Journal of Cultural Property 17, no. 2: 217-55.

Haines, Aaron. 2012. "The Hattusha Sphinx and Turkish Antiquities Repatriation Efforts." Journal of Art Crime 8: 99-103.

Hamilakis, Yiannis. 2007. The Nation and Its Ruins: Antiquity, Archaeology, and National Imagination in Greece. Oxford: Oxford University Press.

Hamilakis, Yannis, and Eleana Yalouri. 1996. "Antiquities as Symbolic Capital in Modern Greece." Antiquity 70: 117-29.

Hitchens, Christopher. 2008. The Parthenon Marbles: The Case for Reunification. London: Verso. 
Hoffman, Barbara, ed. 2009. Art and Cultural Heritage: Law, Policy and Practice. Cambridge: Cambridge University Press.

Houpt, Simon. 2006. Museum of the Missing: A History of Art Theft. New York: Sterling Publishing.

Jonsson, Christer, and Karin Aggestam. 2009. "Diplomacy and Conflict Resolution.” In The Sage Handbook of Conflict Resolution, edited by J. Bercovitch, V. Kremenyuk, and W. Zartman, 33-51. Thousand Oaks: Sage Publications.

Kaye, Lawrence. 1999. "Disputes Relating to the Ownership and Status of Cultural Property." In Resolution Methods for Art-related Disputes, edited by Q. Byrne-Sutton and F. Geisinger-Mariéthoz, 35-54. Etudes en droit de l'art, vol. 11. Zurich: Schulthess.

King, Jamie Litvak. 1999. "Cultural Property and National Sovereignty.” In Ethics of Collecting Cultural Property: Whose Culture? Whose Property?, edited by P. Messenger, 199-208. Albuquerque: University of New Mexico Press.

Kynourgiopoulou, Vasiliki. 2011. "National Identity Interrupted: The Mutilation of the Parthenon Marbles and the Greek Claim for Repatriation." In Contested Cultural Heritage: Religion, Nationalism, Erasure and Exclusion in a Global World, edited by Helaine Silverman, 155-70. New York: Springer.

Lewicki, Roy, David Saunders, and John Minton. 1999. Negotiation, 3rd ed. Boston: Irwin McGraw-Hill.

Listing, Rosemary. 2011. “The Treasure Quest: Peru, Machu Picchu and the Yale Peruvian Expedition of 1911-1916." Art Antiquity and Law 16, no. 1: 67-78.

Mayer, Bernard. 1987. "The Dynamics of Power in Mediation and Negotiation.” Mediation Quarterly 16: 75-86.

Merryman, John H. 1986. "Two Ways of Thinking About Cultural Property." American Journal of International Law 80, no. 4: 831-53.

Monten, Lisa. 2004. "Soviet World War II Trophy Art in Present Day Russia: The Events, the Law, and the Current Controversies." DePaul—LCA Journal of Art and Entertainment Law 15, no. 1:37-98.

Nafziger, James. 2004. “A Blueprint for Avoiding and Resolving Cultural Heritage Disputes.” Art Antiquity and Law 9, no. 1: 3-20.

Nairne, Sandy. 2011. Art Theft and the Case of the Stolen Turners. London: Reaktion Books.

O'Keefe, Patrick. 2007. Commentary on the 1970 UNESCO Convention, 2nd ed. Leicester: Institute of Art and Law.

Palmer, Norman. 2004. “Litigation: The Best Remedy?” In Resolution of Cultural Property Disputes: Papers Emanating from the Seventh Pca International Law Seminar, May 23, 2003 (Permanent Court of Arbitration/Peace Palace Papers), vol. 7, edited by International Bureau of the Permanent Court of Arbitration, 265-90. Dordrecht: Kluwer Law International.

- 2009. "Litigation: The Best Remedy?" In Witnesses to History: Documents and Writings on the Return of Cultural Objects, edited by L. Prott, 358-68. Paris: UNESCO Publishing.

Papa-Sokal, Marina. 2009. "Beyond the Nationalist-Internationalist Polarization in the Protection of Archaeological Heritage: A Response to Professor Merryman." Art Antiquity and Law 14, no. 3: $237-74$. 
Parkhomenko, Konstantin. 2011. "Taking Transnational Cultural Heritage Seriously: Towards a Global System for Resolving Disputes over Stolen and Illegally-Exported Art." Art Antiquity and Law 16, no. 2: 145-60.

Paterson, Robert. 1995. “The Legal Dynamics of Cultural Property Export Controls: Ortiz Revisited.” University of British Columbia Law Review, Special Issue: 241-58.

Pavoni, Riccardo. 2013. "Sovereign Immunity and the Enforcement of International Cultural Property Law." In Enforcing International Cultural Heritage Law, edited by Francesco Francioni, and James Gordley, 79-110. Oxford: Oxford University Press.

Prott, Lyndel. 2010. "The Sphinx within the Wall: A Tale of Two Germanies and Three Sphinxes." Art Antiquity and the Law 15, no. 2: 147-55.

Renold, Marc Andre. 2009. "Arbitration and Mediation as Alternative Resolution Mechanisms in Disputes Relating to the Restitution of Cultural Property." In Crossing Cultures: Conflict, Migration and Convergence-The Proceedings of the 32nd International Congress of the History of Art, 1104-6. Melbourne: Melbourne University Press.

Rothfield, Lawrence, ed. 2008. Antiquities under Siege: Cultural Heritage Protection after the Iraq War. Lanham: Altamira Press.

2009. The Rape of Mesopotamia: Behind the Looting of the Iraq Museum. Chicago: University of Chicago Press.

Scott-Rau, Alan. 1999. "Mediation in Art-Related Disputes." In Resolution Methods for Art-Related Disputes, edited by Q. Byrne-Sutton and F. Geisinger-Mariéthoz, 153-98. Etudes en droit de l'art, vol. 11. Zurich: Schulthess.

Scovazzi, Tullio. 2009. "The Return of the Venus of Cyrene." Art Antiquity and the Law 14, no. 4: 355-58.

Shapiro, Daniel. 1999. "Litigation and Art-Related Disputes." In Resolution Methods for Art-Related Disputes, edited by Q. Byrne-Sutton and F. Geisinger-Mariéthoz, 17-34. Etudes en droit de l'art, vol. 11. Zurich: Schulthess.

Shyllon, Folarin. 2011. "Looting and Illicit Traffic in Antiquities in Africa." In Crime in the Art and Antiquities World: Illegal Trafficking in Cultural Property, edited by S. Manacorda and D. Chappell, 135-42. New York: Springer.

Silver, Vernon. 2009. The Lost Chalice. New York: HarperCollins.

Simpson, Elizabeth, ed. 1997. The Spoils of War: World War II and Its Aftermath: The Loss, Reappearance, and Recovery of Cultural Property. New York: H.N. Abrams, in association with the Bard Graduate Center for Studies in the Decorative Arts.

Stamatoudi, Irini. 2009. "Mediation and Cultural Diplomacy." Museum International 61, no. 1-2: 116-20.

2011. Cultural Property Law and Restitution: A Commentary to International Conventions and European Union Law. IHC Series in Heritage Management. Cheltenham: Edward Elgar Publishing.

Strother, Grant. 2014. "Resolving Cultural Property Disputes in the Shadow of the Law." Harvard Negotiation Law Review 19: 335-76.

Swanson, Stephanie. 2009. "Repatriating Cultural Property: The Dispute between Yale and Peru over the Treasures of Machu Picchu." San Diego International Law Journal 10: 469-94. 
Teixeira, Maria Ines. 2015. “Future Plans, Aggressive Policies? A Look at Turkey’s Heritage Repatriation Strategy." In HISTART '15 : History of Art Conference Proceedings, October 9, 2015, Cezayir Conference Halls, Istanbul Turkey, edited by B. Öztürk, 37-42. Istanbul: Eastern Mediterranean Academic Research Center and Science, Art, Sport Productions.

Ury, William, Jeanne Brett, and Stephen Goldberg. 1988. Getting Disputes Resolved: Designing Systems to Cut the Costs of Conflict. San Francisco: Jossey-Bass Publishers.

Varner, Elizabeth. 2012. "Arbitrating Cultural Property Disputes.” Cardozo Journal of Conflict Resolution 13: 477-526.

Warren, Karen. 1999. "Introduction: A Philosophical Perspective on the Ethics and Resolution of Cultural Property Issues." In Ethics of Collecting Cultural Property: Whose Culture? Whose Property?, edited by P. Messenger, 1-24. Albuquerque: University of New Mexico Press.

Watson, Peter, and Cecilia Todeschini. 2007. The Medici Conspiracy. New York: PublicAffairs.

Waxman, Sharon. 2008. Loot: Tomb Robbers, Treasure and the Great Museum Debate. London: Old Street Publishing.

Wilkie, Nancy. 2009. "Colonization and Its Effect on the Cultural Property of Libya." In Cultural Heritage Issues: The Legacy of Conquest, Colonization, and Commerce, edited by James Nafziger and Ann Nicgorski, 169-83. Leiden: Martinus Nijhoff Publishers.

Yeo, Andrew. 2011. Activists, Alliances and Anti-US Base Protests. New York: Cambridge University Press. 